\title{
Interaction between the entomopathogenic fungus, Beauveria bassiana (Ascomycota: Hypocreales) and the parasitoid wasp, Aphidius colemani Viereck (Hymenoptera: Braconidae)
}

\author{
F. Emami, M. Alichi, K. Minaei \\ Department of Plant Protection, College of Agriculture, Shiraz University, Shiraz, Iran
}

\begin{abstract}
The effect of the entomopathogenic fungus, Beauveria bassiana, on the biological characteristics of Aphidius colemani, a parasitoid of the green peach aphid, Myzus persicae, was studied under laboratory conditions. Third-instar nymphs of green peach aphid were infected with $5 / 3 \times 105$ conidia/mL of $B$. bassiana, which was determined to be the lethal concentration 50 dose. They were then offered to mated female parasitoids for $24 \mathrm{~h}$ at different intervals. Results showed that by prolonging the release intervals of parasitoids, the number of mummies and percent emergence of parasitoids were reduced. Moreover, production of male offspring increased in the F1 generation of parasitoids. The interference of $B$. bassiana with parasitoid development was also studied by first exposing the aphid hosts to the parasitoids for $24 \mathrm{~h}$ and subsequently spraying them with $B$. bassiana $24,48,72$, and $96 \mathrm{~h}$ after exposure. Results showed that by prolonging fungal spraying intervals, the number of mummies and percent emergence of parasitoids were
\end{abstract}

Correspondence: Kambiz Minaei, Department of Plant Protection, College of Agriculture, Shiraz University, Shiraz, Iran.

E-mail: kminaei@shirazu.ac.ir

Key words: Aphidius colemani, Beauveria bassiana, Myzus persicae, interaction, biological control.

Acknowledgements: this manuscript was improved through the advice and critique kindly provided by Dr. Alice Wells (Australian Biological Resources Scientific, Canberra, Australia) and two anonymous referees. The authors are particularly grateful to Dr. Maryam Aleosfoor (Plant Protecting Department, Shiraz University) for valuable comments and guidance. Dr. Mohammad Dadpasand and Dr. Hadi Atashi (Animal Science Department, Shiraz University) are appreciated for helpful comments on the statistical analyses.

Received for publication: 19 0ctober 2012.

Revision received: 11 January 2013.

Accepted for publication: 1 February 2013.

CC Copyright F. Emami et al., 2013

Licensee PAGEPress, Italy

Journal of Entomological and Acarological Research 2013; 45:e4

doi:10.4081/jear.2013.e4

This article is distributed under the terms of the Creative Commons Attribution Noncommercial License (by-nc 3.0) which permits any noncommercial use, distribution, and reproduction in any medium, provided the original author(s) and source are credited. increased. It appeared that the best time for applying $B$. bassiana would be three to four days after parasitisation.

\section{Introduction}

Intra-guild interactions are not limited only to closely related species, but can exist between species from different kingdoms. Despite the competition, there is evidence for mechanisms that reduce antagonistic interaction between natural enemies vying for common insect hosts (Mesquita \& Lacey, 2001). Competition between microorganisms and multicellular animals for nutrition and other requisites is common in nature. However, ecologists have barely started to explore the ecological and evolutionary implications of inter-kingdom competition (Mesquita \& Lacey, 2001). Aphidius colemani (Hymenoptera: Braconidae) is a common parasitoid of aphids, including Myzus persicae (Hemiptera: Aphididae) (Messing \& Rabasse, 1995). The wasp parasitizes all stages of nymphal as well as adult aphids and, under greenhouse conditions, effectively controls the green peach aphid on cotton plants, melons, peppers and cucumbers (Gwan et al., 2001). In biological control, the use of pathogens can be integrated with other natural enemies, and the immediate use of a microbial control agent can protect the crop when parasitoids and predators are unable to maintain the pest population below a damage threshold (Ren et al., 2010). To date, various strains of entomopathogenic fungi such as Beauveria bassiana have been used to control aphids and other pests (Hanh Vu et al., 2007). For success in biological control of pests, entomopathogenic fungi are needed that show high toxicity to pests and low toxicity to non-target insects and other natural enemies (Ren et al., 2010). According to Rashki et al. (2009), Aphidius matricariae and B. bassiana can be used in combination for successful biological control of $M$. persicae (Rashki et al., 2009). However, there is little information on the congeneric wasp, A. colemani, for integrated pest management of $M$. persicae.

The objective of this study was to determine the type of interaction between the entomopathogenic fungus, parasitoid wasp and its host, the green peach aphid. Moreover, the impact of $B$. bassiana on biological parameters of $A$. colemani was evaluated.

\section{Materials and methods}

\section{Fungus}

Beauveria bassiana strain DEBI008 from the culture collection at the Biocontrol Laboratory of Shiraz University was used. After passage of the fungus through $M$. persicae, it was cultured on potato dextrose agar 
with yeast extract (PDA) for 2 weeks at $25^{\circ} \mathrm{C}$. The average viability of conidia used in the various tests was $94.7 \%$ as determined on PDA using standard techniques (Goettel \& Inglis, 1997). This involved inoculating an 8-cm Petri plate containing PDA with $100 \mathrm{~mL}$ of a suspension containing $10^{6}$ conidia/mL and counting the percentage of germinated conidia in four separate areas on the plate after incubation at $25^{\circ} \mathrm{C}$ for $18-20 \mathrm{~h}$ (Jenkins et al., 1998). Germination was considered positive when the length of the germ tube was as long as the diameter of the conidia. During the test, the lethal concentration 50 dose $\left(5.3 \times 10^{5}\right.$ conidia $\left./ \mathrm{mL}\right)(1$ $\mathrm{mL}$ per spray application) was used for third instar nymphs of the aphid by application in a Potter spray tower (Potter, 1952).

\section{Host plant and insect colonies}

Sweet peppers, Capsicum annuum var. annuum, were grown individually in plastic pots (15 cm diameter, $12 \mathrm{~cm}$ height) to provide experimental host plants. Myzus persicae and Aphidius colemani from aphid mummies were collected from tomato fields in Badjgah (15 km north of Shiraz). M. persicae was reared on sweet peppers in a controlled environment room $\left[21 \pm 1^{\circ} \mathrm{C}, 60 \pm 5 \%\right.$ relative humidity (RH), $\left.16 \mathrm{~L}: 8 \mathrm{D}\right] . A$. colemani was reared on $M$. persicae inside a plexiglas box $(50 \times 60 \times 60$ $\mathrm{cm})$ in a controlled environment room $\left(25 \pm 1^{\circ} \mathrm{C}, 70 \pm 5 \% \mathrm{RH}, 16 \mathrm{~L}: 8 \mathrm{D}\right)$. A. colemani females (4-5 days old) were used for all experiments except those to determine longevity.

\section{Aphids first exposed to the parasitoid and then treated with the fungus}

Fifteen replicated tests were conducted on separate dates, each replicate containing 40 third-instar aphids. Each group was placed in a Petri dish (80 mm diameter) containing a leaf of Capsicum annuum, fitted into the Petri dish with a hole $(2 \mathrm{~cm}$ diameter) in the lid covered with a fine mesh screen for ventilation (Baverstock et al., 2009). The leaves were fixed in $2 \%$ water-agar. Aphids were exposed to a 4-5-days old female A. colemani. After $24 \mathrm{~h}$, the parasitoids were removed. The replicates of parasitized aphids were sprayed with $B$. bassiana at a concentration of $5.3 \times 10^{5}$ conidia/mL in $0.02 \%$ Tween $80,24,48,72$, or $96 \mathrm{~h}$ after exposure to the parasitoids. The control was also treated with $0.02 \%$ Tween 80 . After $24 \mathrm{~h}$ of fungal conidial application to the aphids, the lids of the Petri dishes were replaced with new lids without holes and sealed with parafilm to maintain a saturated humidity to facilitate conidial germination. Dead aphids were counted daily for 1 week and were placed on water agar ( $3 \mathrm{~g}$ of agar/L of water) to confirm infection by $B$. bassiana. During the experiment, the Petri dishes were kept inverted and incubated at $25^{\circ} \mathrm{C}$, under a $16: 8 \mathrm{~h}$ photoperiod and $70-85 \% \mathrm{RH}$.

\section{Aphids first treated with fungus and then exposed to the parasitoid}

Forty third-instar aphids were used in each of 15 replicates. All were treated with $5.3 \times 10^{5}$ conidia/mL B. bassiana in $0.02 \%$ Tween 80 . The aphids were then exposed to a 4-5-days old female $A$. colemani at different time intervals following application of the fungus. The following combinations of treatments were tested: exposure to the parasitoid 0 , 24,48 , or $72 \mathrm{~h}$ after application of the fungus, or no fungus (control). The control was also treated with $0.02 \%$ Tween 80 . Fifteen replicates were set up. Each group of 40 aphids was maintained on a leaf set up in $2 \%$ water-agar in a Petri dish ( $80 \mathrm{~mm}$ diameter). As described above, during the first $24 \mathrm{~h}$ following treatments, the Petri dishes were hermetically sealed. Then the cover was replaced with one having a screened opening. The inverted Petri dishes were kept at 70-75\% RH, $25^{\circ} \mathrm{C}$, and 16:8 h photoperiod. As described above, dead aphids were recorded daily for 1 week and were placed on water agar to confirm infection by $B$. bassiana. The number of mummies produced were recorded and the time of pre-imaginal parasitoid development, percentage of emergence, sex ratio and longevity of the F1 generation females were determined. For studying pre-imaginal parasitoid development (mummification until emergence as well as oviposition until emergence) upon formation of the mummies, they were maintained individually in a test tube until adult emergence. To investigate longevity of female parasitoids, they were maintained individually in a Petri dish ( $80 \mathrm{~mm}$ diameter) under the above conditions and fed with a honey solution (60\%).

\section{Statistical methods}

The data were analyzed in a completely randomized design using Proc GLM in SAS (1999). The treatments were compared using Duncan's multiple range test at a significance level of 0.05 . The data were normalized using arcsin transformation when necessary.

\section{Results}

\section{Aphids first exposed to the parasitoid and then treated with the fungus}

The number of mummies produced varied significantly among different intervals and between treatments and the control (Table 1). The lowest percentage of F1 emergence of $A$. colemani was found for those which developed in aphids treated with $B$. bassiana $24 \mathrm{~h}$ after exposure to the female parasitoid. Results showed that by prolonging the fungal spraying intervals, the number of mummies and percent emergence of parasitoids were increased.

\section{Aphids first treated with fungus and then exposed to the parasitoid}

As seen in Table 2, the number of mummies varied significantly among treatments. In all treatment groups, the numbers of mummies produced were significantly lower compared with the control. The least

Table 1. Least squares means $( \pm \mathrm{SE})$, number of Aphidius colemani mummies, and percentage of adult parasitoids emerging from $M y z u s$ persicae exposed to the parasitoid and then sprayed with Beauveria bassiana $(B b)\left(5 / 3 \times 10^{5}\right.$ conidia/mL $24,48,72$, and $96 \mathrm{~h} \mathrm{later}$.

\begin{tabular}{|c|c|c|c|c|}
\hline Treatments & $\begin{array}{l}\text { No. aphids exposed to } \\
\qquad A C\end{array}$ & $\begin{array}{l}\text { No. aphids treated with fungus } \\
\text { After exposure to } A C\end{array}$ & $\begin{array}{l}\text { No. mummies produced by } \\
\qquad A c\end{array}$ & $\begin{array}{l}\% \text { Emergence of F1 } \\
\text { Generation of } A c\end{array}$ \\
\hline Only $A c$ & 40 & - & $32.0 \pm 0.77^{a}$ & $94.1 \pm 3.9^{a}$ \\
\hline$A c+B b(24 \mathrm{~h})$ & 40 & $35.1 \pm 1.1$ & $9.5 \pm 0.99^{d}$ & $19.4 \pm 4.6^{\mathrm{e}}$ \\
\hline$A c+B b(48 \mathrm{~h})$ & 40 & $34.9 \pm 1.2$ & $18.4 \pm 1.75^{c}$ & $46.1 \pm 5.9^{d}$ \\
\hline$A c+B b(72 \mathrm{~h})$ & 40 & $33.5 \pm 1.1$ & $25.1 \pm 1.66^{b}$ & $61.2 \pm 0.5^{c}$ \\
\hline$A c+B b(96 \mathrm{~h})$ & 40 & $33.2 \pm 1.3$ & $26.2 \pm 1.15^{b}$ & $75.8 \pm 5.3^{b}$ \\
\hline
\end{tabular}

Ac, Aphidius colemani; Bb, Beauveria bassiana. a,b,c,d Least squares means followed by the same letter in the same column are not significantly different at the 0.05 level. 
number of mummies were found when parasitism occurred $72 \mathrm{~h}$ after exposure to $B$. bassiana and the greatest numbers were recorded when exposure to the fungus and parasitoid occurred at the same time.

There was a significant difference in the time period from oviposition to mummification, ranging from $5.0 \pm 0.1$ to $3.2 \pm 0.1$ days among treatments (Table 3 ). In the presence of the fungus, the time between mummy formation and female emergence was decreased. The shortest interval occurred when the aphids were exposed to the parasitoids $72 \mathrm{~h}$ after fungal treatment or infestation. However, fungal infection of the aphids only reduced the time between mummification and male emergence of the parasitoids when the hosts were exposed to parasitoid attack $72 \mathrm{~h}$ after fungal infection (Table 3 ). Therefore, compared with the development of $A$. colemani in uninfected hosts, total developmental times for males and females were significantly shorter in hosts attacked $72 \mathrm{~h}$ after fungal infection. There was also a significant difference in adult female longevity of $A$. colemani ranging from $8.4 \pm 0.3$ to $6.4 \pm 0.2$ days among treatments (Table 4 ).

\section{Discussion and conclusions}

The number of mummies and percent emergence of parasitoids increased by prolongation of the fungal spraying intervals (Table 1), suggesting that older parasitoid larvae have a high probability of winning the competition for the host aphid, possibly due to a low susceptibility to fungal infection (Fransen \& van Lenteren, 1994). This supports the opinion that the presence of a fungistatic substance secreted by the parasitoid into the hemolymph of the host impedes the development of mycosis and enables normal parasitoid development and emergence (Mesquita \& Lacey, 2001). The inhibitory effect of parasitoids on the development of mycosis in parasitized hosts is normally linked to the time interval between parasitism and contamination of the host by the fungus (Powell et al., 1986). Aphidius colemani developed normally when its host aphid (Aphis gossypii) was treated with Verticillum lecanii conidia 5 or 7 days after parasitization. Moreover, numbers of

Table 2. Least squares means $( \pm \mathrm{SE})$, number of Aphidius colemani mummies produced, percent adult emergence of $\mathrm{F} 1$ generation, and percentage of females in the F1 generation from Myzus persicae sprayed with Beauveria bassiana and then parasitized 0, 24, 48, and 72 h later.

\begin{tabular}{lrcc} 
Treatments & No. of mummies produced & \% Emergence of F1 generation & Percentage of females in F1 generation \\
Only $A c$ & $26.7 \pm 1.5^{\mathrm{a}}$ & $89.2^{\mathrm{a}} \pm 1.9^{\mathrm{a}}$ & $66.7 \pm 0.01^{\mathrm{a}}$ \\
$B b+A c(0 \mathrm{~h})$ & $10.2^{\mathrm{a}} \pm 0.6^{\mathrm{b}}$ & $51.8 \pm 4.6^{\mathrm{b}}$ & $61.6 \pm 0.06^{\mathrm{a}}$ \\
\hline$B b+A c(24 \mathrm{~h})$ & $8.1 \pm 0.7^{\mathrm{b}}$ & $35.8 \pm 3.5^{\mathrm{c}}$ & $58.3 \pm 0.1^{\mathrm{a}}$ \\
$B b+A c(48 \mathrm{~h})$ & $4.3 \pm 0.6^{\mathrm{c}}$ & $21.3 \pm 5.2^{\mathrm{d}}$ & $39.6 \pm 0.1^{\mathrm{ab}}$ \\
\hline$B b+A c(72 \mathrm{~h})$ & $2.3 \pm 0.5^{\mathrm{c}}$ & $15.8 \pm 6.1^{\mathrm{d}}$ & $26.7 \pm 0.1^{\mathrm{b}}$ \\
\hline
\end{tabular}

Ac, Aphidius colemani; Bb, Beauveria bassiana. ${ }^{\text {a,b,c, } \mathrm{d}}$ Least squares means followed by the same letter in the same column are not significantly different at the 0.05 level.

Table 3. Developmental time (least squares means \pm SE) of Aphidius colemani when aphids were first exposed to Beauveria bassiana and then parasitized $0,24,48$, and $72 \mathrm{~h}$ later.

\begin{tabular}{|c|c|c|c|}
\hline Treatments & Oviposition until mummification (day) & $\begin{array}{l}\text { Mummificat } \\
\text { 우 }\end{array}$ & $\underset{0}{(\text { day })}$ \\
\hline Only $A c$ & $5.0 \pm 0.1^{\mathrm{a}}$ & $5.0 \pm 0.00001^{\mathrm{a}}$ & $4.5 \pm 0.02^{\mathrm{a}}$ \\
\hline$B b+A c(0 \mathrm{~h})$ & $4.8 \pm 0.04^{\mathrm{a}}$ & $4.3 \pm 0.008^{\mathrm{b}}$ & $4.5 \pm 0.1^{\mathrm{a}}$ \\
\hline$B b+A c(24 \mathrm{~h})$ & $4.3 \pm 0.06^{\mathrm{b}}$ & $4.8 \pm 0.06^{\mathrm{a}}$ & $4.3 \pm 0.1^{\mathrm{a}}$ \\
\hline$B b+A c(48 \mathrm{~h})$ & $3.5 \pm 0.08^{\mathrm{c}}$ & $4.5 \pm 0.1^{\mathrm{b}}$ & $4.1 \pm 0.1^{\mathrm{a}}$ \\
\hline$B b+A c(72 \mathrm{~h})$ & $3.2 \pm 0.1^{\mathrm{d}}$ & $4.3 \pm 0.3^{b}$ & $4.0 \pm 0.00001^{\mathrm{a}}$ \\
\hline
\end{tabular}

Ac, Aphidius colemani; Bb, Beauveria bassiana. ${ }^{\mathrm{a}, \mathrm{b}, \mathrm{c}, \mathrm{d}}$ Least squares means followed by the same letter in the same column are not significantly different at the 0.05 level.

Table 4. Developmental time and adult female longevity (least squares means \pm SE) of Aphidius colemani when aphids were first exposed to Beauveria bassiana and then parasitized $0,24,48$, and $72 \mathrm{~h}$ later.

\begin{tabular}{|c|c|c|c|}
\hline Treatments & \multicolumn{2}{|c|}{ Oviposition until emergence (day) } & ale longevity (day) \\
\hline Only $A C$ & $10.0 \pm 0.17^{a}$ & $9.5 \pm 0.008^{\mathrm{a}}$ & $9.8 \pm 0.03^{\mathrm{a}}$ \\
\hline$B b+A c(0 \mathrm{~h})$ & $9.1 \pm 0.09^{b}$ & $9.3 \pm 0.3^{\mathrm{ac}}$ & $8.4 \pm 0.3^{b}$ \\
\hline$B b+A c(24 \mathrm{~h})$ & $9.1 \pm 0.08^{b}$ & $8.6 \pm 0.3^{b c}$ & $7.0 \pm 0.3^{c}$ \\
\hline$B b+A c(48 \mathrm{~h})$ & $8.0 \pm 0.2^{c}$ & $7.6 \pm 0.3^{\mathrm{d}}$ & $6.4 \pm 0.2^{c}$ \\
\hline$B b+A c(72 \mathrm{~h})$ & $7.5 \pm 0.2^{\mathrm{d}}$ & $7.2 \pm 0.3^{\mathrm{d}}$ & $6.5 \pm 0.1^{\mathrm{c}}$ \\
\hline
\end{tabular}

Ac, Aphidius colemani; Bb, Beauveria bassiana. ${ }^{\mathrm{a}, \mathrm{b}, \mathrm{c}, \mathrm{d}}$ Least squares means followed by the same letter in the same column are not significantly different at the 0.05 level. 
spores and mycelial fragments in aphid homogenates were much higher in those exposed to the fungus up to 3 days after parasitization compared with the aphids treated after 5 or 7 days (Kim et al., 2005).

As noted in Table 2, with prolongation of the release intervals of parasitoids, the production of male offspring increased in the F1 generation of parasitoids (Table 2). This is almost the same situation that antibiotic treatments cause some female parthenogenetic strains of Trichogramma wasps to revert to production of male progeny (Stouthamer et al., 1990). A high proportion of male offspring in many parasitic Hymenoptera may indicate virginity or sperm depletion in parental females or a manipulated sex ratio (deposition of unfertilized eggs to produce male offspring) (Godfray, 1994). If such constrained females reproduce, the population sex ratio will shift toward males and unconstrained females will be selected to produce more females (Fauvergue et al., 1998). A female parasitoid may face several types of competition from females of her own species or from different species. The strategies evolved by parasitoids to cope with competition have implications both for the population dynamics of the species and for their use as biological control agents (Boivin \& Brodeur, 2006).

In this study, by prolonging the release intervals of parasitoids, the number of mummies produced and percent emergence of parasitoids were reduced (Table 2). This may indicate the lack of larval survival potential in infected hosts, following by decreased oviposition of the adult parasitoids in the $72 \mathrm{~h}$-infected hosts and fungus-killed groups. The presence of hyphal bodies or fungal metabolites in the hemolymph of the host detected by the parasitoid at the time of ovipositor insertion are apparently the cause of rejection of these hosts for oviposition (Brobyn et al., 1998). Fransen and van Lenteren (1993) demonstrated that the parasitoid Encarsia formosa laid fewer eggs in the greenhouse whitefly, Trialeurodes vaporariorum, infected by the fungus Aschersonia aleyrodis than in uninfected hosts. Brobyn et al. (1988) found that Aphelinus asychis and Aphidius rhopalosiphi did not attempt to oviposit in fungus-killed aphids. Furthermore, it is shown that by prolonging the release intervals of parasitoids, fungus-infected aphids have more opportunities for growth and increased competitiveness, which may lead to death of the wasp larvae (Brodeur \& Rosenheim, 2000). On the other hand, the present results show a reduction in longevity of pre-imagos and adult parasitoids developing within hosts infected by $B$. bassiana (Table 3 ), presumably because they provide lower quality food for the feeding immatures (Nouhuys \& Laine, 2008). Presence of the parasitoid wasps apparently reduces the risk of the host becoming infected with fungus as a pre-adult (Lecuona et al., 2007).

In most cases, the interactions between fungal pathogens and natural enemies are positive (Roy \& Pell, 2000). The present study revealed that the best time for treating $M$. persicae with $B$. bassiana was 3-4 days after parasitation by $A$. colemani. Therefore, with proper timing, this wasp could potentially be used in combination with $B$. bassiana for successful biological control of an economically important aphid such as $M$. persicae.

\section{References}

BAVERSTOCK J., CLARK S.J., ALDERSON P.G., PELL J.K., 2009 Intraguild interactions between the entomopathogenic fungus Pandora neoaphidis and an aphid predator and parasitoid at the population scale. - J. Invert. Path. 102: 167-172.

BOIVIN G., BRODEUR J., 2006 - Intra- and interspecific interactions among parasitoids: mechanisms, outcomes and biological control. - Biol. Control. 3: 123-144.

BROBYN P.J., CLARK S.J., WILDING N., 1998 - The effect of fungus infection of Metopolophium dirhodum [Hom.: Aphididae] on the oviposition behaviour of the aphid parasitoid Aphidius Rhopalosiphi [Hym.: Aphidiidae]. - Entomophaga 33: 333-338.
BRODEUR J., ROSENHEIM J.A., 2000 - Intraguild interactions in aphid parasitoids. - Entomol. Exp. App. 97: 93-108.

FAUVERGUE X., HOPPER K.R., ANTOLIN M.F., KAZMER D., 1998 - Does time until mating affect progeny sex ratio? A manipulative experiment with the parasitoid wasp Aphelinus asychis. - J. Evol. Biol. 11: 611-622.

FRANSEN J.J., VAN LENTEREN J.C., 1993 - Host selection and survival of the parasitoid Encarsia formosa on greenhouse whitefly, Trialeurodes vaporariorum, in the presence of hosts infected with the fungus Aschersonia aleyrodis. - Entomol. Exp. App. 69: 239-249.

FRANSEN J.J., VAN LENTEREN J.C., 1994 - Survival of the parasitoid Encarsia formosa after treatment of parasitized greenhouse whitefly larvae with fungal spores of Aschersonia aleyrodis. - Entomol. Exp. App. 71: 235-243.

GODFRAY H.C.J., 1994 - Parasitoids behavior and evolutionary ecology. - Princeton University Press, Princeton, NJ, USA.

GOETTEL M.S., INGLIS G.D., 1997 - Fungi: Hyphomycetes. In: LACEY L.A., ed., Manual of techniques in insect pathology. - Academic Press, London: 213-249.

GWAN G.H., KIM J.H., HAN M.W., 2001 - Application of Aphidius colemani Viereck for control of the aphid in Greenhouse. - J. Asia Pac. Entomol. 4: 171-174.

HANH Vu V., HONG S.I., KIM K., 2007 - Selection of entomopathogenic fungi for aphid control. - J. Biosci. Bioeng. 104: 498-505.

JENKINS N.E., HEVIEFO G., LANGEWALD J., CHERRY A.J., LOMER C.J., 1998 - Development of mass production technology for aerial conidia for use as mycopesticides. - Biocontrol News Inf. 19: 29-39.

KIM J.J., KIM K.C., ROBERTS D.W., 2005 - Impact of the entomopathogenic fungus Verticillium lecanii on development of an aphid parasitoid, Aphidius colemani. - J. Invert. Path. 88: 254-256.

LECUONA R., CRESPO D., ROSSA F., 2007 - Populational parameters of Spalangia endius Walker (Hymenoptera: Pteromalidae) on pupae of Musca domestica L. (Diptera: Muscidae) treated with two strains of Beauveria bassiana (Bals.) Vuil. (Deuteromycetes). - Neot. Entomol. 36: 537-541.

MESQUITA A.L.M., LACEY L.A,. 2001 - Interactions among the entomopathogenic fungus, Paecilomyces fumosoroseus (Deuteromycotina: Hyphomycetes), the parasitoid, Aphelinus asychis (Hymenoptera: Aphelinidae), and their aphid host. - Biol. Control 22: 51-59.

MESSING R.H., RABASSE J.M., 1995 - Oviposition behaviour of the polyphagous aphid parasitoid Aphidius colemani Viereck (Hymenoptera: Aphidiidae). - Agric. Ecosyst. Environ. 25: 13-17.

NOUHUYS S., LAINE A.L., 2008 - Population dynamics and sex ratio of a parasitoid altered by fungal-infected diet of host butterfly. - R. Soc. 275: 787-795.

POTTER C., 1952 - An improved apparatus for applying direct sprays and surface films with data on the electrostatic charge on atomized spray fluids. Ann. Appl. Biol. 39: 1-28.

POWELL W., WILDING N., BROBYN P.J., CLARK S.J., 1986 - Interference betwee parasitoids [Hym.: Aphidiidae] and fungi [Entomophthorales] attacking cereal aphids. - Entomophaga 31: 293-302.

RASHKI M., KHARAZMI A., PAKDEL A., ALLAYHARI H., VAN ALPHEN J.J.M., 2009 - Interactions among the entomopathogenic fungus, Beauveria bassiana (Ascomycota: Hypocreales), the parasitoid, Aphidius matricariae (Hymenoptera: Braconidae), and its host, Myzus persicae (Homoptera: Aphididae). - Biol. Control 50: 324-328.

REN S.X., ALI S., HUANG Z., WU J.H., 2010 - Lecanicillium muscarium as microbial insecticide against whitefly and its interaction with other natural enemies. - Microbiol. Microbial. Biotechnol. 27: 339-348.

ROY H.E., PELL J.K., 2000 - Interactions between entomopathogenic fungi and other natural enemies: implications for biological control. - Biocontrol Sci. Technol. 10: 737-752.

SAS, 1999 - User's Guide: Statistics. Version 9. - SAS Institute Inc., Cary, NC, USA.

STOUTHAMER R., LUCK R.F., HAMILTON W.D., 1990 - Antibiotics cause parthenogenetic Trichogramma (Hymenoptera/Trichogrammatidae) to revert to sex. - Proc. Natl. Acad. Sci. U. S. A. 87: 2424- 27. 